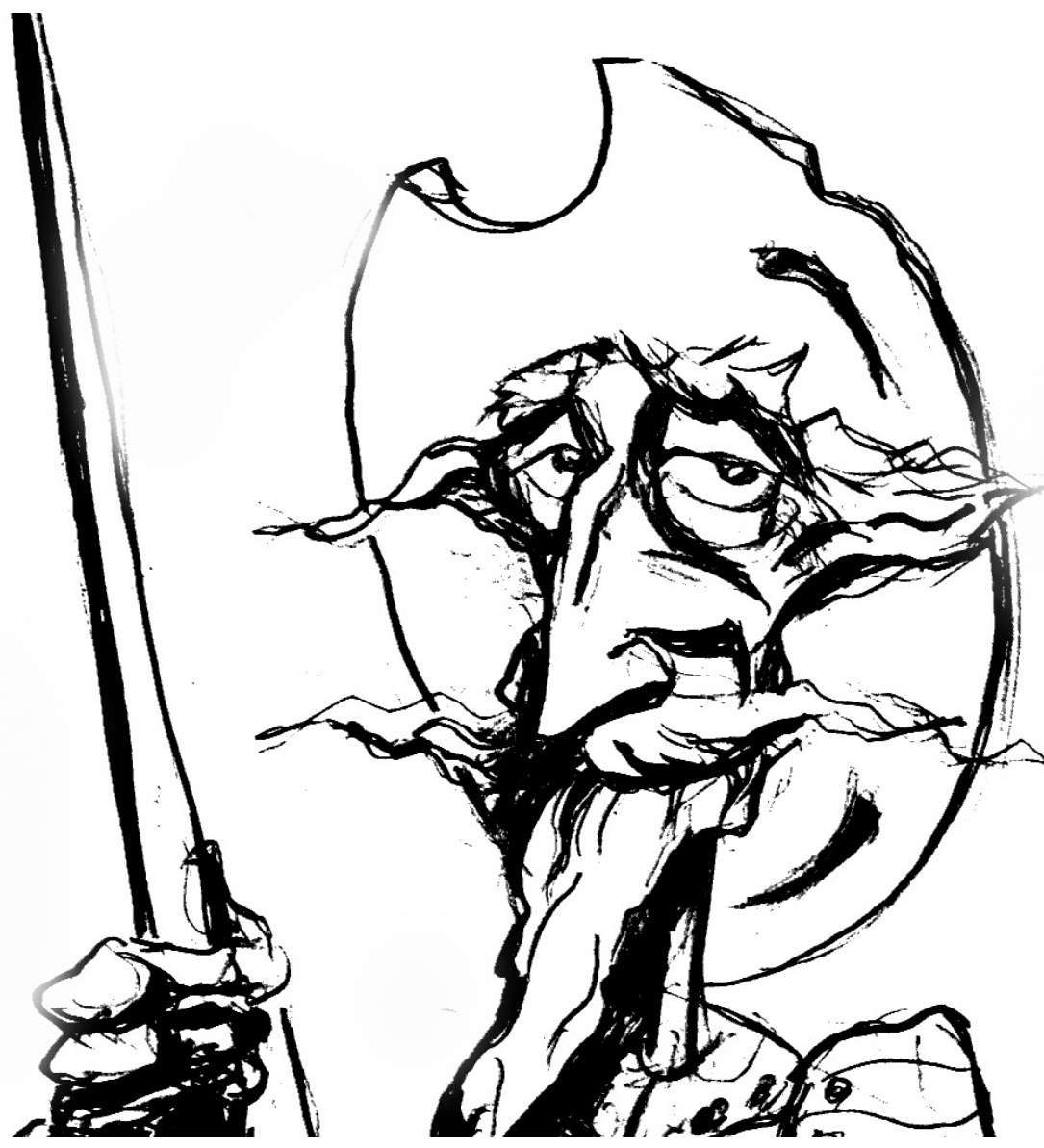

Viajeros ilustrados y la Disputa del Nuevo Mundo: Alexandre Rodrigues Ferreira y Tadeo Haenke ante el hombre americano

[Muriel Morgan] 



\title{
Viajeros ilustrados y la Disputa del Nuevo Mundo: Alexandre Rodrigues Ferreira y Tadeo Haenke ante el hombre americano*
}

\section{Enlightened Travelers and the New World Dispute: Alexandre Rodrigues Ferreira and Tadeo Haenke before the American Man}

\author{
MURIEL MORGAN
}

\section{Resumen}

El debate sobre la naturaleza de América, que tuvo lugar a mediados del siglo XVIII en pleno auge de los grandes viajes científicos y de exploración, confrontó a aquellos que defendían la excepcionalidad del Nuevo Mundo frente a aquellos que sostenían su condición degenerada. La condena o reivindicación del hombre americano, surgidas como corolarios de esta discusión, se vincularon con un debate más amplio sobre el proyecto ilustrado para encontrar constantes en la naturaleza humana. En el terreno de la ciencia, esta polémica profundizó tanto la dicotomía naturaleza y cultura como la preeminencia de una por sobre la otra como factor explicativo de la diferencia. Teniendo en cuenta este contexto, el presente artículo analiza los escritos de Alexandre Rodrigues Ferreira y Tadeo Haenke, dos viajeros científicos que recorrieron la América Meridional, comparando sus antecedentes, objetivos y fundamentalmente sus explicaciones sobre la diversidad humana.

Palabras clave Naturaleza del Nuevo Mundo; Tadeo Haenke; Alexandre Rodrigues Ferreira

\begin{abstract}
The debate on American nature, which took place in the mid 18th century at the peak of the great scientific and exploratory voyages, confronted those who defended the exceptional nature of the New World with those who maintained its degenerated condition. The condemnation or vindication of the American man, emerged as a corollary of this discussion, were linked to a broader debate on the enlightened project to find constants in human nature. In the field of science this controversy deepened the Nature/Culture dichotomy as well as the preeminence of one over the other as the explanatory factor of the difference. With this context in mind, this paper analyzes the writings of Alexandre Rodrigues Ferreira and Tadeo Haenke, two scientific voyagers who travelled through Meridional America, comparing their backgrounds, objectives and mainly their explanations of human diversity.
\end{abstract}

\section{Keywords}

Nature of the New World; Tadeo Haenke; Alexandre Rodrigues Ferreira.

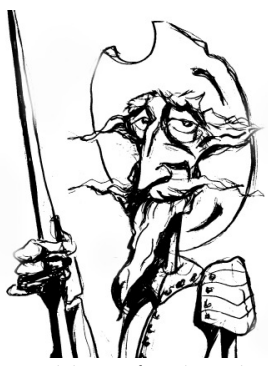

Recibido con pedido de publicación el 20 de marzo de 2020

Aceptado para su publicación el 2 de junio de 2020

Versión definitiva recibida el 13 de julio de 2020

Muriel Morgan, Instituto de Altos Estudios Sociales, Universidad Nacional de San Martín, Consejo Nacional de Investigaciones Científicas y Técnicas, Buenos Aires, Argentina; e-mail: murielmo@gmail.com

\footnotetext{
*Agradezco los aportes de los evaluadores anónimos de la revista.

Esta obra se publica bajo licencia Creative Commons. Atribución-NoComercial-CompartirIgual 4.0 Internacional $(\mathrm{cc})$ EY-NC-SA
}

Morgan, Muriel “Viajeros ilustrados y la Disputa del Nuevo Mundo: Alexandre Rodrigues Ferreira y Tadeo Haenke ante el hombre americano", Prohistoria, Año XXIII, núm. 34, dic. 2020, pp. 131-158. 


\section{Introducción}

El XVIII fue el siglo de los grandes viajes científicos y de exploración: un programa de conciencia planetaria que implicó conocer los interiores continentales y otros territorios desconocidos (Pratt, 1997). Estas expediciones conjugaron intereses económicos, territoriales y científicos ya que entre sus objetivos se encontraba la consolidación de los territorios coloniales, el descubrimiento de nuevos recursos y la extensión de las rutas comerciales. En este sentido, las prácticas científicas constituyeron una importante forma de control de la naturaleza y la sociedad, por lo que este inventario del mundo no puede separarse del proceso de conquista (Nieto Olarte, 2003). De estas expediciones surgió un nuevo tipo de narrativa: la literatura de viajes científica. En esta narrativa se impusieron nuevos criterios de verosimilitud, en consonancia con los nuevos credos empiristas y experimentalistas. Por un lado, antes de dar cuenta de los aspectos maravillosos o insólitos, existió un afán por brindar una testificación neutra, detallada y minuciosa de las realidades naturales (Pimentel, 2003: 63). ${ }^{1}$

Por el otro, la autoridad del viajero ilustrado dependió de una presencialidad que había sido resignificada: importaba ser testigo ("haber estado allí"), pero también su capacidad, competencia e imparcialidad (Pagden, 1993). En este proceso, la naturaleza misma de la autoridad fue tensada y transformada, ya que el fortalecimiento de la autóptica desgastaba la autoridad basada en el conocimiento heredado, constituido por un canon de textos bíblicos y greco-romanos (Pagden, 1993). ${ }^{2}$ La tensión dinámica entre entendimientos previos y nuevas experiencias (Schwartz, 1994: 2) fue característica del relato de viajes moderno, culminando en la pretensión de objetividad de la narrativa ilustrada. En este sentido, autores anteriores como Oviedo o Las Casas jamás afirmaron ser observadores neutrales e imparciales o que sus registros eran desapasionados, a diferencia de sus sucesores (Pagden, 1993: 69). No podían, ni tenían, la intención de ofrecer prueba de su objetividad.

A su vez, debemos remarcar que esta presencialidad se privilegiaba a partir de la competencia del viajero, legitimada por su condición de científico. ${ }^{3}$ El establecimiento

\footnotetext{
${ }^{1}$ Pimentel (2003) ha abordado el vínculo entre credibilidad y testimonio de los viajeros, analizando el proceso de construcción de verosimilitud que culminó en la pretensión de objetividad del viajero ilustrado. En su trabajo demuestra el pasaje de las tácticas de representación de principios de la Edad Moderna, a las empleadas durante la Ilustración. Sobre la importancia del asombro y lo maravilloso en las primeras representaciones del Nuevo Mundo ver Greenblatt (2008).

${ }^{2}$ La autóptica, una categoría de la retórica antigua, es definida por Pagden como la apelación a la autoridad del testigo presencial y al entendimiento privilegiado que aquellos que presencian un evento tienen sobre los que solo lo leyeron (1993:51).

${ }^{3}$ Esta transformación en el estatus, rol e imagen del observador culminó, para Pagden, en la figura de Humboldt como viajero científico, cuyas observaciones no estaban ratificadas tanto por sus métodos o instrumentos experimentales, como por la seguridad que tenía en la autoridad de su yo: el ojo de un hombre de ciencia (Pagden realiza aquí un juego de palabras entre " $I$ " (уо) y "eye" (ojo). (1993: 87).
} 
de una comunidad científica global contribuyó a la legitimación de los viajeros y de sus relatos. La noción de ciencia como un patrimonio colectivo, donde los resultados eran comunicables y replicables, estableció un tipo de narrativa pretendidamente unificada en la que cada sujeto contribuía (Pimentel y Lucena Giraldo, 2006). ${ }^{4}$ Las Academias de Ciencia avalaron la competencia de sus miembros, quienes a su vez participaron en esta construcción y acumulación colectiva de conocimiento. Se puede argumentar que así como en el siglo XV existió un canon de textos bíblicos y grecorromanos que proporcionaron los esquemas a través de los cuales se comprendió el Nuevo Mundo, en el siglo XVIII surgió un nuevo paradigma: el de los científicos y filósofos ilustrados, que condicionaron a su manera las observaciones. En este sentido, era necesario hacer inteligible mediante el canon todo aquello que se viera o fuese demostrable por experimento y aquella evidencia que no entraba en los esquemas conceptuales y por ende forzaba los paradigmas podía ser manipulada o forzada (Pagden, 1993:11). A pesar de la importancia del testimonio directo como fuente privilegiada de información, veremos cómo en ciertas ocasiones los viajeros ajustaron los datos empíricos para encuadrarse con los teóricos de la época.

Siguiendo a Kupperman (1995), para el siglo XVIII América había sido aceptada como parte del paisaje mental europeo y era hora de evaluar su impacto. Las discusiones científicas sobre el Nuevo Mundo se incrementaron. En este contexto, la figura del "salvaje" volvió a ser actual y los europeos se interrogaron sobre la naturaleza del hombre (Hartog, 2005). ${ }^{5} \mathrm{La}$ "Disputa del Nuevo Mundo" fue un debate sobre la naturaleza de América, que implicaba no solo su lugar en la historia natural sino su participación en el mundo político, económico y social, es decir su papel en el orden global (Gerbi, 1982). ${ }^{6}$ La condena o reivindicación del hombre americano,

\footnotetext{
4 Según Pimentel y Lucena Giraldo (2006), la objetividad es un fenómeno histórico en el que el conocimiento se construye no a partir de la uniformidad de los fenómenos sino de la homogeneidad de los testigos.

${ }^{5}$ Entendemos como "buen salvaje" a las distintas representaciones idealizadas y utópicas de los pueblos considerados primitivos por los europeos: una personificación de la vida natural y virtuosa. Fernández Herrero identifica los origenes de este mito en la etapa inmediatamente posterior a la llegada de Colón a América y no, como suele hacerse habitualmente, con el pensamiento ilustrado, en particular con la idea de Estado de Naturaleza de Rousseau (1989). De acuerdo a Lestringant (1993), en el siglo XVIII se dio una resignificación de la figura del buen salvaje, convirtiéndolo en un portavoz maleable de sus preocupaciones: la alabanza a la libertad natural, la lucha contra la opresión institucional y un anticatolicismo militante. Fue representado, entonces, como un heraldo de los derechos imprescriptibles de la naturaleza contra la arbitrariedad de las reglas sociales y religiosas. Para un desarrollo de la elaboración del mito del buen salvaje y la leyenda negra de la conquista española durante la Edad Moderna ver Cro (1989).

${ }^{6}$ Como analiza Martínez (2015), este fue también un debate sobre fuentes, planteando que en tanto el estatus y la naturaleza de América fueron objeto de escrutinio, se reevaluó la veracidad de los testimonios. Se dio una tendencia a juzgar la validez de un relato en función de su análisis interno y no de
} 
surgidos como corolarios de esta discusión, se vinculaban con un debate más amplio sobre el proyecto ilustrado para encontrar constantes en la naturaleza humana (Pagden, 1993). En este trabajo compararemos las memorias de viaje de Alexandre Rodrigues Ferreira (1783-1792) y Tadeo Haenke (1799), centrándonos en sus contribuciones y posturas ante esta disputa. Sugerimos que una comparación entre las concepciones de Haenke y Rodrigues Ferreira sobre el hombre americano nos permite observar la tensión ilustrada entre los principios de universalidad y el reconocimiento de la diversidad humana, mostrando las distintas maneras de concebir esta preocupación fundamental del pensamiento del siglo XVIII. Asimismo, la dicotomía naturaleza/cultura, así como la preeminencia de una sobre la otra como factor explicativo anticipan las discusiones científicas sobre el hombre que se darán en los siglos posteriores.

\section{El contexto intelectual ilustrado: entre la doctrina de la perfectibilidad del hombre y el reconocimiento de la diferencia cultural}

Una de la reflexiones sobre el hombre que más impacto tuvo en el Iluminismo fue la de John Locke (1632-1704), quien sostenía que la mente humana al nacer era un gabinete vacío, una tabula rasa. Es decir que al ser la razón adquirida, no hereditaria, diferentes experiencias producirían diferencias individuales y sociales en la conducta (Harris, 1996). ${ }^{7}$ Sin embargo, la maleabilidad de creencias y costumbres no implicaba que no existieran creencias morales universalmente válidas, así como normas y modos de conducta correctos y erróneos. La razón, correctamente aplicada, llevaría al hombre a las mismas instituciones sociales y creencias morales, a las mismas verdades (Harris, 1996). Esta doctrina de la perfectibilidad del hombre implicaba que al estudiar su

las aptitudes o cualidades del testigo presencial. Los primeros relatos sobre América perdieron credibilidad y se cuestionó la fiabilidad de los testigos presenciales. En este contexto, los defensores de la naturaleza americana continuaron enfatizando la autoridad de lo visto, aunque basándose en testigos considerados más confiables. Así, como propone Cañizares Esguerra (2007), en España se desarrolló una renovación historiográfica que privilegió el uso de "fuentes primarias" en detrimento de las impresas.

7 A pesar de que la Ilustración europea fue un movimiento preocupado por los mismos problemas intelectuales, existieron diversas corrientes al interior: el cartesianismo, que proponía una dicotomía de la sustancia, de las cuales solo una estaba sujeta a las leyes de la causa y el efecto; el empirismo inglés, entre el que se encontraba Locke, que postulaba que solo se puede conocer lo que es probado que opera mecánicamente mediante la experimentación; finalmente el pensamiento de Spinoza quien, para Israel, fue el pilar de la construcción del pensamiento científico ilustrado. Spinoza estableció la noción de racionalidad científica que rechazaba los argumentos, creencias y tradiciones que entrasen en conflicto con las leyes de la naturaleza. Así, consideraba que la filosofía natural era aplicable universalmente, que todo lo que existe obedece a las mismas reglas y rechazando la existencia de otra realidad más allá de estas leyes que gobernaban la naturaleza. En Spinoza, las operaciones de la razón filosófica se integraban con la investigación empírica, en tanto consideraba que los sentidos eran el eslabón débil (Israel, 2001). 
naturaleza no solo se sabía lo que es sino lo que es posible: conocer permitía criticar y cambiar instituciones hasta lograr un mundo basado en la razón y la verdad (Zeitlin, 1968). Sin embargo, estos modelos de conocimiento social, que emulaban al modelo newtoniano, no lograban explicar la diversidad humana (Zeitlin 1968, Harris 1996, Schwartz, 1994). Esta tensión entre la idea de universalidad y el reconocimiento de la diversidad humana y cultural real (Schwartz, 1994) se reflejó en la discusión sobre el hombre americano. En este sentido, el problema de fondo de la polémica sobre la naturaleza americana se dio en torno a los conceptos de progreso y humanidad, los valores contrapuestos del primitivismo y la civilización.

Tanto la tradición bíblica como el pensamiento ilustrado sostenían la unidad psíquica del hombre, por lo que las diferencias se debían o bien a causas morales e históricas o bien por influencia del medio natural. Surgieron entonces una serie de explicaciones evolucionistas que dividían a la sociedad humana en etapas: cazadores, pastores y agricultores (según Turgot); salvajes, bárbaros y civilizados (para autores como Montesquieu y Robertson). Para pensadores como Dégerando, las distintas sociedades que coexistían representaban distintas etapas de esta escala (Stocking, 1982). La obra sobre los diez estadios de la humanidad desarrollados por Condorcet fue la culminación del esfuerzo ilustrado por interpretar la evolución sociocultural en términos del incremento del contenido racional de los pensamientos, costumbres e instituciones (Harris, 1996). En tanto existía una unidad psíquica del hombre, en tanto existían verdades absolutas y en tanto que la sociedad europea (francesa) era el ideal y la culminación del desarrollo de la razón, era el deber de los europeos educar y civilizar a otras sociedades. Esta misión civilizadora reemplazó a la legitimación religiosa de la colonización, cobrando fuerza en el siglo siguiente (Outram, 2008). ${ }^{8}$

A finales del siglo XVIII cobraron fuerza las explicaciones de causación ambiental como fundamento del evolucionismo social, en las que se interrelacionaron los conocimientos de la historia natural y de la teoría social. Uno de los teóricos más importantes del determinismo ambiental fue Georges Louis Leclerc, Conde de Buffon, quien afirmaba que existía una conexión orgánica de lo viviente con el ambiente, y en tanto los caracteres físicos no eran inmutables, la variabilidad en las especies era producto de la combinación de factores ambientales con el tiempo (Urteaga, 1993). ${ }^{9} \mathrm{Su}$

\footnotetext{
8 En una línea similar, Cicerchia (2000) estima que la ciencia reemplazó a la religión como ideología de legitimación de la dominación imperial. La promesa de un progreso indefinido postulado por el proyecto científico estableció a la colonización como un gesto de solidaridad humana.

${ }_{9}$ Buffon fue crítico de la imagen fijista y estática de la taxonomía de Linneo, oponiendo su propia clasificación que reflejaba el dinamismo del mundo viviente, al incorporar no solo las características anatómicas de las especies sino su hábitat (Urteaga, 1993). Linneo, creador de la nomenclatura binomial base de la taxonomía moderna, tuvo una gran importancia en los trabajos de Haenke y Rodrigues Ferreira. A pesar de ser creacionista, el naturalista sueco insinuó, a través de su nomenclatura, el parentesco entre las especies y además ubicó a los hombres en este sistema de clasificación biológica.
} 
tesis sobre la "debilidad" o "inmadurez" del continente americano desencadenó la denominada Disputa del Nuevo Mundo (Gerbi, 1982). Esta teoría sostenía que todas las especies tenían un único origen en el Viejo Mundo, debilitándose por motivos ambientales al emigrar a América. Este había sido el último continente en emerger de las aguas, por lo que era un Nuevo Mundo tanto en un sentido geológico como figurativo. Este continente no se había secado, por lo que era húmedo, frío y en estado de putrefacción. La evidencia para la teoría de la degradación se encontraba en la menor cantidad de especies americanas, en su mayoría más pequeñas o débiles que en el Viejo Mundo. Esta hipótesis parecía confirmarse con la disminución del tamaño de los animales domésticos que se habían introducido, mientras que la proliferación y tamaño de reptiles e insectos se explicaba por la humedad y putrefacción americanas, un ambiente favorable para este tipo de especies (Gerbi, 1982:11). ${ }^{10}$ Aunque menos condenados que los animales, los hombres americanos no habían podido dominar a esta naturaleza hostil y continuaban controlados por ella. La causa era su naturaleza fría y su frigidez en el amor, similares al continente, que limitaban sus deseos de domarla. ${ }^{11} \mathrm{~A}$ medida que fue desarrollando su teoría, Buffon fue moderando esta creencia, hasta negar la degeneración del hombre y limitarla a los animales (Gerbi, 1982:38).

El abate holandés Cornelius De Pauw, por el contrario, desarrolló la teoría de la degradación hasta llegar a sostener que los americanos eran física y mentalmente inferiores a los europeos como consecuencia de la naturaleza del continente. Sus habitantes eran hombres estúpidos, inertes e indolentes, incluso los criollos quienes reflejaban la degeneración de los europeos debido a la naturaleza (Gerbi, 1982:126). ${ }^{12}$ De Pauw no fue el único en discutir el carácter condenable del americano. El Abate Raynal, por su parte, aunque no compartía la noción de degradación, afirmaba que los americanos carecían de deseo de progreso y por eso no podían transformar la naturaleza en algo útil. América era en consecuencia un mundo destruido moral y materialmente (Bernand, 2009: 116). El escocés Robertson sostenía la existencia de una única evolución de la humanidad en cuatro estadios (subsistencia, ganadería,

\footnotetext{
${ }^{10}$ Para Buffon los organismos eran más perfectos cuanto menos habían variado y a mayor tamaño, mayor era la inmutabilidad. El cambio los debilitaba, exponiéndolos a mayores mutaciones, siendo esta la causa de su degradación (Gerbi, 1982:21).

${ }^{11}$ Las ideas de Buffon impactaron incluso en España. Jovellanos, por ejemplo, consideraba que el comprender el ambiente en su totalidad permitía que el hombre lo remodelara a través del desarrollo científico-tecnológico y de programas políticos. Es decir que se podía luchar contra la naturaleza cuando estorbaba (Capel, 1995)

${ }^{12}$ Aunque crítico de los excesos de los ibéricos, sostenía que los americanos habían progresado gracias a la civilización europea, que purificaba el ambiente malsano. No obstante, el primer De Pauw de 1768, limitó este progreso a los ingleses sosteniendo que los españoles y portugueses se habían contagiado de la pereza de los indígenas. Sus publicaciones fueron fuertemente criticadas por entusiastas defensores del buen salvaje y de la naturaleza virgen, así como por criollos como Benjamin Franklin y Francisco Clavijero (Gerbi, 1982; Kupperman 1995).
} 
agricultura y sociedad comercial), explicando las diferencias con argumentos similares a los de Buffon y Raynal: la carencia de deseo inhibía el progreso. ${ }^{13} \mathrm{El}$ salvaje, indolente e inerte emocional y sexualmente, era un individuo con necesidades empobrecidas y en consecuencia, imaginación empobrecida. Por oposición, el hombre civilizado tenía necesidades complejas que lo habían llevado a controlar la naturaleza (Pagden, 1993).

La controversia sobre la naturaleza americana estuvo teñida de un componente propagandístico, disfrazado de cientificidad, que reflejaba rivalidades políticas, militares y económicas más amplias (De Vos, 2009). Para España, estas nuevas teorías tenían el atractivo de la modernidad y una oportunidad de insertarse en el proyecto ilustrado europeo. Sin embargo, la caracterización negativa de América, sumado al cuestionamiento de las fuentes ibéricas, no podían desvincularse del ataque protestante al colonialismo español en un contexto de disputas imperiales. En efecto, esta nueva batalla ideológica y cultural contra España y su sistema colonial se vio facilitada por la existencia de un viejo paradigma: el de la leyenda negra antiespañola (Cañizares Esguerra, 2007). Encontramos opiniones a favor del hombre americano, como las de Benito Jerónimo Feijoo (1676-1764), Lorenzo Hervás y Panduro (1735-1809) o Félix de Azara (1742-1821), quienes continuaron la tradición lascasiana de denuncia contra los abusos a indígenas, así como detractores como Jorge Juan (1713-1773) y Antonio de Ulloa (1716-1795).

En general, la Ilustración española fue un movimiento patriótico, en la que la defensa de la identidad y la patria fueron acompañadas por llamados a renovar la economía y la cultura. La resistencia a una representación caricaturesca de la "mente española" por parte de otros europeos y la noción de que los dominios coloniales eran perdidos o ganados por aquellos que controlaban las descripciones de los territorios y los pueblos, impulsaron los viajes científicos (Cañizares Esguerra, 2007). A su vez, los gobiernos borbónicos buscaron controlar el discurso sobre América, censurando y editando textos ilustrados antiespañoles y promoviendo la publicación de obras filoespañolas que defendieran el honor nacional, en particular en lo relativo a la Conquista (Guasti, 2014). Autores como De Pauw y Raynal fueron censurados por la Inquisición, tanto por su descalificación de la colonización española, como por sus ataques sistemáticos contra la religión, los eclesiásticos y la Corona llevaron a que muchos fuesen censurados (González Montero de Espinosa, 1992). ${ }^{14}$ Por otra parte,

\footnotetext{
${ }^{13}$ El debate entre Robertson y Clavijero implicaba también una discusión sobre fuentes. Para Robertson, la posibilidad de tener una historia dependía de la escritura, entendida como el análisis crítico de los textos, mientras que Clavijero introdujo otro tipo de fuentes iconográficas, arqueológicas y pictóricas, a las que sumó su experiencia y conocimiento directo. Para un análisis en profundidad ver Sebastiani (2011).

${ }^{14}$ Este no fue el caso de Robertson, quien destacaba los méritos de la colonización española, la que se había esforzado por educar a unos nativos infantiles, insensibles y perezosos. Esta opinión
} 
aunque Buffon fue ampliamente difundido en España, su traductor Pedro de Estala publicó su obra incluyendo juicios propios, corrigiendo y comentando aquellos puntos que consideraba problemáticos (Soriano Muñoz, 2020).

En Portugal, el movimiento ilustrado dependía fuertemente del apoyo estatal: las academias de ciencia y literarias habían sido fundadas por la Corona y en los dominios coloniales, se encontraban bajo el severo escrutinio de las autoridades virreinales (Ventura, 1988). Este contexto, sumado a la censura y al control estrecho de las lecturas, limitaba la posibilidades de divulgación de las obras y la circulación de ideas (Coelho, 2000). A su vez, la impronta pragmática y utilitarista que el reformismo pombalino dio a la ilustración portuguesa, limitó el alcance de los debates. La decadencia económica, la inestabilidad política y las amenazas sobre su imperio resultaron discusiones más urgentes que las discusiones europeas sobre historia natural (Rodriguez García, 2017). Sin embargo, estaba presente la idea que la política indigenista implementada por Pombal en América lograría civilizar a los salvajes americanos (Albuquerque de Miranda, 2018). En este sentido, algunos exponentes de la degradación americana fueron utilizados como justificación científica y teórica a las políticas asimilacionistas pombalinas. Por ejemplo, para Coelho (2000) este sería el caso de Rodrigues Ferreira quien, en ocasiones, se comporta como un funcionario colonial, evaluando la implementación de las políticas asimilacionistas, en particular en relación con diversos proyectos agrícolas. ${ }^{15}$

\section{Los viajeros}

Alexandre Rodrigues Ferreira nació en Bahía el 27 de abril de 1756. Egresó como Preparador de Historia Natural en la Universidad de Coimbra, donde luego se doctoró en 1779. Al año siguiente ingresó como miembro de la Real Academia de Ciencias de Lisboa. En julio de 1778 fue destinado a una misión de ultramar a pedido de Martinho de Mello e Castro, Ministro y Secretario de Estado de Negocios y Dominios Ultramarinos. ${ }^{16}$ La Viagem Filosofica pelas Capitanias do Grao-Para, Rio Negro, Mato Grosso e Ciuabá fue el resultado de este viaje de exploración realizado entre 1783 y 1792. Está

probablemente explique su popularidad en España y su incorporación a la Academia de Historia de Madrid, como contrapunto a aquellos intelectuales europeos que alimentaban la leyenda negra.

${ }^{15}$ La controversia sobre la naturaleza y el hombre americanos tuvo un gran peso entre los intelectuales de los dominios coloniales ibéricos. Cañizares Esguerra (2007) ha ampliado el análisis de Gerbi, incorporando las contradicciones y tesiones de la conciencia hispano-criolla, aprisionada entre la arrogancia europea y el racismo local. Sobre la contraofensiva hispanocriolla ver Bernand (2009) y Sebastiani (2011). En Brasil, Domingues (2001) ha analizado el vínculo entre las tesis de la degradación americana con las disputas políticas surgidas en Brasil entre el reformismo pombalino y las élites lusocriollas.

${ }_{16}$ Misiones similares fueron enviadas a Cabo Verde, Angola y Mozambique (Melo Carvalho, 1972). 
compuesto por los manuscritos y diarios de viajes registrados por Rodrigues Ferreira y fueron sistematizados por primera vez en 1887. Regresó a Lisboa en 1793 donde llegó a ser Vicedirector del Real Gabinete de Historia Natural y Jardín Botánico. Murió el 23 de abril de 1815 (Melo Carvalho, 1972).

Thaddeus Peregrinus Haënke (Tadeo Häenke o Haenke en Iberoamérica) nació en Bohemia el 6 de diciembre de 1761. Estudió botánica, medicina y mineralogía en las Universidades de Praga y Viena. En 1789 fue admitido a la expedición Malaspina gracias a una solicitud de la Corona de España. Su incorporación fue accidentada: en primer lugar, navegó solo a América al perder la partida de las corbetas Descubierta y Atrevida; su barco naufragó en el Río de la Plata y salvó su vida abrazado a sus tomos de Linneo; finalmente, se incorporó a la expedición en Santiago de Chile, tras atravesar el continente por tierra. Tras la Expedición se radicó en Cochabamba, donde se desempeñó como asesor naturalista del Intendente Francisco de Viedma. Murió en un accidente doméstico en 1817 (Balta, 1901). ${ }^{17}$

En este trabajo analizaremos la Viagem Filosofica (1972) de Rodrigues Ferreira y la Descripción del Perú (1901), la Memoria sobre los Ríos Navegables (1901) y la Historia Natural de Cochabamba (1809) de Haenke. ${ }^{18}$ La primera derivó de una gran expedición cuyo objetivo principal era realizar un inventario exhaustivo del Brasil, así como recoger productos de los reinos de la naturaleza y remitirlos al Real Museo de Lisboa con las correspondientes observaciones filosóficas. ${ }^{19}$ El naturalista brasileño fue acompañado por dos ilustradores, Joaquim José Codina y José Joaquim Freire, y el jardinero botánico Agostinho Joaquim do Cabo.

Su agenda científica se vio condicionada por su rol de naturalistas al servicio de los intereses imperiales: debía describir potenciales recursos económicos, reconocer recorridos fluviales, informar sobre la colonización portuguesa y realizar observaciones sobre el adelanto en la agricultura (Rodríguez García, 2015). Su maestro Vandelli, impulsor de los viajes filosóficos, elaboró instrucciones generales y específicas para cada uno de ellos: se trata de manuales consagrados al trabajo de campo y al transporte de productos, que enfatizan la localización de recursos explotables, y en los que puede observarse la influencia de las directrices dadas por Linneo a sus discípulos (Moutinho

\footnotetext{
${ }^{17}$ Estando Haenke enfermo, su criada confundió los frascos de remedios y el botánico murió envenenado. ${ }^{18}$ La Descripción del Perú fue publicada en Lima en 1901 incluyendo la Memoria sobre ríos navegables como anexo. La Historia Natural fue publicada en 1809 como anexo a los Voyages dans l'Amérique Méridional de Félix de Azara y nunca fue traducida al castellano. El primero de estos textos fue escrito en 1790, mientras que los otros dos lo fueron en 1799. Rodrigues Ferreira fue publicado por primera vez recién en 1887, a pesar de que su viaje fue realizado entre 1783 y 1792. La traducción de fragmentos del portugués y el francés es nuestra.

${ }^{19}$ Las memorias y el material zoológico fueron incautados para el Museo de París durante las invasiones napoleónicas.
} 
Pataca y Pinheiro, 2005)..$^{20}$

Los textos de Haenke que hemos examinado corresponden a viajes de menor escala: una memoria redactada con información recolectada antes de su incorporación a la expedición de Malaspina y dos informes realizados para la Intendencia de Cochabamba. El Intendente Francisco de Viedma, su protector, contrató a Haenke como "naturalista residente" y le ordenó realizar diversas misiones oficiales, como por ejemplo el reconocimiento de los ríos de la región o una prolongada estancia entre los grupos indómitos chiriguanos en 1806 (Navallo, 2011). Como hemos indicado, estas producciones fueron realizadas en un contexto político económico cuando las coronas ibéricas vieron su dominio colonial disputado por otras potencias europeas. Estas autoridades imperiales y coloniales, que financiaban las expediciones, también delimitaban el alcance de los objetivos. España consideraba que un mayor conocimiento de sus territorios ultramarinos se traduciría en un aumento de su poderío político y económico (Nieto Olarte, 2003). Aunque compartimos con Schwartz (1994) que se debe prescindir de una formulación extrema del argumento representacional, en que lenguaje y representación equivale a poder y posesión, es innegable que este inventario científico tuvo un impacto directo en la reconfiguración de las relaciones coloniales (Schwartz, 1994). ${ }^{21}$

Las grandes expediciones científicas recibieron instrucciones específicas sobre lo que debía ser registrado y era relevante para la Corona (Pimentel, 2003). Lo mismo puede observarse en viajes más modestos como los de Haenke. Este "modo de visualidad", el acto de ver, seleccionar y recortar de la masa de conocimiento, fue producto de la nueva relación entre metrópoli y colonia impulsada por el reformismo borbónico (Penhos, 2005). En esta nueva etapa de dominación colonial, España abandonó la extracción de minerales preciosos como base de la prosperidad metropolitana, para reemplazarla con un incipiente mercantilismo. En este sentido, los programas borbónicos y pombalinos eran similares, considerando que el comercio era la base de la prosperidad social. Por este motivo tanto Haenke como Rodrigues Ferreira incluyeron en sus descripciones naturalistas nuevas posibilidades de explotación económica y comercial. Por ejemplo, aunque Viagem corresponde a una gran expedición, con intereses científicos explícitos, describe por ejemplo la explotación económica de la tortuga y del manatí. Por otra parte, las motivaciones económicas de Haenke son indiscutibles y en ocasiones sus textos se asemejan a Visitas de gobierno: Descripción cuenta con información sobre comercio y tributos de la Real Hacienda del Perú, la flora y fauna de Historia Natural incluye en su descripción sus potencialidades

\footnotetext{
${ }^{20}$ En su trabajo, estas autoras han rastreado la continuidad e influencia de los Viajes Filosóficos en la ciencia brasileña del siglo XIX (Moutinho Pata y Pinheiro, 2005).

${ }^{21}$ Greenblatt también advierte sobre los riesgos de erradicar la distinción entre representación y realidad, pero sostiene que no pueden mantenerse aisladas la una de la otra (2008).
} 
económicas específicas y Memoria plantea la posibilidad de establecer una ruta comercial navegable, evitando el peligroso y costoso cruce de los Andes. ${ }^{22}$ También incluyó en estas obras propuestas de industrias americanas, desaprovechadas o desconocidas. $^{23}$

La diferencia de formación entre Haenke y Rodrigues Ferreira se evidencia en sus escritos. Rodrigues Ferreira estudió Filosofía Natural y Matemática en la universidad de Coimbra, recibiendo el cargo de Preparador en Historia Natural. Su mentor fue el famoso naturalista y botánico italiano Domenico Vandelli, quien delineó las instrucciones científicas de todas las expediciones portuguesas. En Viagem, no hay descripción de minerales y la sección de flora es muy pobre. Sin embargo, la sección de zoología constituye un inventario total de las especies de Brasil, y en la sección de antropología describe a todos los grupos humanos que había encontrado. Las constantes referencias en este texto a filósofos, naturalistas y viajeros ilustrados revelan su interés por participar activamente en las principales discusiones sobre América.

Haenke también se inició como naturalista, especializándose en medicina, botánica y mineralogía. Sus maestros fueron Joseph Gottfried Mittan, botánico y químico, y Nikolaus Joseph von Jacquin, profesor de química y mineralogía. Su Historia Natural consiste en una clasificación exhaustiva de sustancias minerales, naturales y artificiales, y vegetales, de acuerdo a su uso medicinal y comercial. La sección zoológica se limita a los camélidos andinos y el hombre casi no es mencionado. Sus distintos escritos evidencian su compromiso con la monarquía borbónica y con funcionarios como Francisco de Viedma, de quien fue asesor científico, así como su creencia en la misión evangelizadora y civilizadora de España. Esto no le impedía admirar a Francia, alabando su "... entusiasmo de proteger los derechos de la humanidad y de las gentes, esta poderosa potencia aliada y amiga de España” (Haenke, 1901: 317). Consideramos que Haenke era un humanista que creía firmemente en el progreso de la humanidad y que su apoyo a la Corona no se debía únicamente a su vínculo laboral. Su simpatía por la labor misional y su primera intención de ser misionero (Krizová, 2013) encontraron

\footnotetext{
${ }^{22}$ La botánica era particularmente importante para España por sus posibles usos medicinales y comerciales, por lo que se fomentó su estudio en América y se promocionó la industria farmacéutica (Nieto Olarte, 2003). Haenke, en su doble condición de botánico y médico, es un reflejo de esta preocupación.

${ }^{23} \mathrm{~A}$ modo de ejemplo resumiremos su proyecto para la industria textil por considerarlo representativo del pensamiento ilustrado de Haenke. América contaba con excelentes algodonales mientras que la lana era de la mejor calidad, en particular la de llamas y vicuñas (un recurso único en el mundo). A partir de experimentos realizados sobre el terreno, conocía las sustancias minerales y vegetales para teñirlas. Además, la industria textil proporcionaría empleo: "para hacer de esta clase de personas, sujetos laboriosos y útiles al rey, al Estado y a sí mismos, y para detener los desórdenes que nunca dejan de causar la ociosidad y la holgazanería" (Haenke, 1809: 537). Por su calidad, la materia prima podría reemplazar a la asiática, más costosa, y la manufactura competir con los mejores textiles europeos.
} 
una continuidad en el proyecto borbónico.

El léxico empleado por los dos viajeros muestra la diferencia de intereses, aunque ambos utilicen la taxonomía linneana. Haenke utiliza un latín preciso para vegetales y minerales pero no para referirse a los animales, llegando incluso a cometer errores de aficionado, como por ejemplo llamar tigre al jaguar o pez al manatí. ${ }^{24}$ Rodrigues Ferreira clasifica a partir del sistema natural de Linneo añadiendo nombres locales e indígenas, generalmente en lengua tupí. Por ejemplo, el pez arapaima gigas figura como pez pirarucú,el nombre genérico con el que se lo denomina incluso hoy día, pero recalca que el nombre deriva de pirá-urucu por el color de sus escamas (urucu es rojo en tupí). Las quince variedades de tortugas son descritas a partir de sus nombres locales, muchos indígenas: iurará--uaçu, iurará-acânga-uaçu o iurará-uirapequê. La descripción de los animales incluye su anatomía y su uso, ya sea como alimento o herramienta. En este sentido, los cuadrúpedos fueron clasificados en "comestibles", "sólo comidos por indios y por algunos blancos en el monte" y "no comestibles".

\section{La Disputa}

Rodrigues Ferreira se involucró directamente en el debate sobre la naturaleza de América que se dio en Europa a finales del siglo XVIII. Sus reflexiones combinaban lecturas de historiadores y filósofos con sus propias experiencias, posicionándose como testigo calificado, objetivo y neutral. En particular se evidencia la influencia de Buffon, cuyas teorías son frecuentemente retomadas y contrastadas con observaciones empíricas, como por ejemplo la de la degradación americana. Escribía que en la América Meridional era notable la exuberancia vegetal, por lo que "Era de esperarse que aquí, semejante a las selvas del antiguo continente, fuesen estas habitadas también por grandes y feroces animales como elefantes, rinocerontes, tigres y leones. No es verdad, no es así" (Rodrigues Ferreira, 1972: 70). Los mamíferos eran menores en cantidad, en volumen y en robustez que los del Viejo Mundo: "Parece que estos pequeños cuadrúpedos [...] sean de una raza inferior visto que en volumen mayor de todos de aquí es el tapir, y en ferocidad, el jaguar". (Rodrigues Ferreira, 1972: 71). Sin embargo, lo contrario sucedía con reptiles, serpientes e insectos..$^{25} \mathrm{Su}$ hipótesis era que los vegetales abundaban por una combinación del calor del sol, la humedad y la fertilidad del terreno, pero que el "principio" de la vida animal no compartía la fuerza y actividad de la vegetal. Las causas que disminuían la fuerza y volumen de los animales mayores, favorecían la proliferación de los pequeños. Sin embargo, no identifica estas

\footnotetext{
${ }^{24}$ Rodrigues Ferreira se burlaba de un cura que le había consultado si podía consumir manatí durante la cuaresma, por no saber si era pez o mamífero.

${ }^{25}$ Otras excepciones eran los caballos, puercos y venados, pero probablemente no tiene en cuenta estas observaciones en sus razonamientos por contradecir las principales tesis de Buffon.
} 
causas ni desarrolla la idea de "principio de vida".

Como naturalista Rodrigues Ferreira también se interesó por el hombre, incluyéndolo en la sección de zoología como uno de los seis tipos de mamíferos según la taxonomía linneana. Se preocupó por profundizar el análisis de la variedad Americanus del Homo, a la que denominó Tapuia. ${ }^{26} \mathrm{Al}$ igual que Ulloa y de Cieza León, a quienes cita como referencia, consideraba que los americanos eran físicamente iguales, con una combinación de facciones específica y un cierto aire "tan primitivamente suyo" (Rodrigues Ferreira, 1972:75). Es interesante considerar que a pesar de haber nacido en Brasil, se consideraba un portugués. En este sentido, las reflexiones europeas se vieron repetidas por europeos-americanos que participaban de una cultura relacionada pero separada (Kupperman, 1995:18).

Uno de los principales enigmas intelectuales por los que se preocupó fue el de la diferencia en el color de la piel. La explicación tradicional de esta diversidad era la existencia de una zona tórrida del globo que oscurecía la piel y en consecuencia, aquellos hombres que se encontraban en el Ecuador eran negros. América, donde todos los hombres eran castaños o cobre, contradecía esta teoría. Para Rodrigues Ferreira, como para Buffon, las diferencias se debían a una menor exposición al calor el Nuevo Mundo, cuyas temperaturas eran más bajas debido a los Andes y al Amazonas. ${ }^{27}$

Los tapuias eran físicamente más ágiles que fuertes, habilidosos para remar en canoas, cazar, pescar y nadar. Sin embargo eran perezosos y rechazaban trabajos más pesados como el agrícola: "Los gentiles, alimentados o no, son enemigos del trabajo porque no pueden hacerlo cuando les falta alimento y cuando ricos, no quieren" (Rodrigues Ferreira, 1972: 83). Como muchos de sus contemporáneos, Rodrigues Ferreira consideraba que la causa se encontraba en la Naturaleza del continente, pero no porque su frialdad o podredumbre se hubiesen transmitido a los hombres, sino por su

\footnotetext{
${ }^{26}$ El Homo Diurnus se dividía en tres especies: Ferus, Monstrosus y Sapiens, que a su vez se subdividía en cuatro variedades que combinaban observación y prejuicio: Americanus (colorado, colérico, obstinado, amante de la libertad, gobernado por la costumbre), Europeus (blanco, sanguíneo, inconstante, inventivo, gobernado por leyes), Asiaticus (amarillo, melancólico, severo, avaro, gobernado por la opinión), Afer (negro, flemático, perezoso, negligente, gobernado por impulso). Homo Monstrosus comprendía ciertas anomalías humanas como gigantes, pigmeos y humanos con deformaciones craneanas. Homo Ferus incluía ciertos individuos criados por animales y que tenían características bestiales, como el niño lobo de Hesse o la niña salvaje de Champagne (Malik, 1992). El género Homo incluía otro tipo de criaturas antropomorfas dentro de la clasificación genérica de Homo Nocturnus o Troglodytes, que comprendía especies como el Homo Sylvestris (un simio racional) o el Homo Caudatus (un hombre con cola) a quien su alumno Hoppius rebautizó Homo Lucifer Adrovandi (Malik, 1992). Como veremos, Rodrigues Ferreira se ocupó de especular y discutir las concepciones linneanas sobre el género Homo.

${ }_{27}$ Buffon sostenía además que la inmadurez del americano no había permitido que el color se asentase (Urteaga, 1993). Esta teoría fue refutada por el naturalista y matemático Paolo Frisi en 1771 en su discusión con De Pauw (Gerbi, 1982).
} 
exuberancia. Todo les era ofrecido sin grandes fatigas y sus limitados deseos y necesidades podían ser satisfechos con un mínimo de trabajo. En este punto se separa de su gran maestro Buffon y sus concepciones de un hombre americano inerte. En efecto, la relación entre ambiente y seres vivientes es una tesis no resuelta en Rodrigues Ferreira: el clima americano era tan benéfico que aumentaba la longevidad tanto de blancos como de tapuias, pero sostenía que el "principio vital" de los mamíferos era menor. Consideramos que esta discordancia surge de su esfuerzo por conciliar las contradicciones entre sus observaciones y las teorías de Buffon.

El espíritu del tapuia surgía como consecuencia de la exuberancia vegetal: “Estos privilegios que los gentiles disfrutan, debe resultar del hecho que sus cuerpos no son oprimidos por trabajos ni sus espíritus por aquellas meditaciones y sinsabores que inquietan y atribulan a los hombres civilizados" (Rodrigues Ferreira, 1972: 85). Para definir este espíritu, Rodrigues Ferreira citó en sus escritos las opiniones de viajeros, naturalistas y funcionarios, como La Condamine que consideraba que la insensibilidad formaba parte del carácter americano y sus ideas no se extendían más allá de sus necesidades o el padre Miguel Venegas, quien al meditar sobre los californios sostuvo que en tanto sus requisitos naturales eran pocos, también lo eran sus esfuerzos espirituales y corporales, desconociendo el honor, la reputación o cualquier otro tipo de distinción. Como hemos indicado, para Rodrigues Ferreira la aversión al trabajo no se debía a la incapacidad mental de los americanos sino a su pereza, vinculada con la fecundidad excesiva de la naturaleza. En consecuencia, su habilidad para razonar se había visto inhibida: "Hay quien dice que su sensibilidad a los dolores es menor que la nuestra, por la contextura de su piel y de su contextura física [...] No es que les falten alientos o voces para manifestar sus gustos y dolores, pero es que ellos, fuera del tumulto de las pasiones, no son hombres que desperdicien palabras. Acostumbrados a pensar poco, también hablan poco" (Rodrigues Ferreira, 1972: 99 y 100). También se equivocaban quienes sostenían, como Buffon, que el americano era frío e inerte en el amor. Al contrario, eran promiscuos e impúdicos pues en tanto el ambiente garantizaba la subsistencia, "el hambre, la peste y la guerra no distraen del amor [...] lo cierto es que cuanto más nutrido y flojo anda el cuero, tanto más ardiente se hace aquel apetito" (Rodrigues Ferreira, 1972: 97).

Además de especular sobre la variedad Americanus, Rodrigues Ferreira contrastó la taxonomía linneana del género Homo con los datos recolectados en Brasil. Dentro de la especie de Homo Monstrosus, existían aquellos que lo eran por naturaleza o por artificio, como por ejemplo los omagua que se achataban la frente, los miranha y caripunas que agujereaban su nariz y los gamela quienes distendían sus labios. Rodrigues Ferreira también registró como se lograban estas deformaciones. Con respecto a los monstruosos por naturaleza, se preguntó si los ugina (hombres con cola) eran reales, ya que su existencia era sostenida no solo por muchos testimonios sino por 
la taxonomía de Linneo, deduciendo finalmente que debían ser deformidades particulares, como una extensión de la espina dorsal, más que una especie. Su conclusión respecto a estas criaturas era que las fábulas del Viejo Mundo habían resucitado en el Nuevo, poblado de seres humanos monstruosos y fantásticos, como gigantes, pigmeos y cíclopes. Al explorar los lugares habitados por seres extraordinarios se comprobaba que estaban habitados por americanos ordinarios. Para Rodrigues Ferreira, a medida que la naturaleza era observada por ojos ejercitados en lugar de "viajeros crédulos", iban desapareciendo las maravillas y los cuentos ignorantes. Es decir, la autoridad estaba sostenida no por el testimonio del observador sino por el rol de científico. ${ }^{28}$

Aunque Tadeo Haenke no participó abiertamente de la Disputa del Nuevo Mundo, el debate no pudo haberle sido ajeno. Su entusiasmo por la naturaleza americana lo acercaba más a La Condamine que a Buffon. El Nuevo Mundo tenía recursos casi infinitos, el jardín botánico más rico y útil del mundo y animales de gran variedad y hermosura. Las aves eran incalculables y vistosas, la cantidad de cuadrúpedos era indecible y solo era lamentable la abundancia de insectos y culebras. $\mathrm{Su}$ aprecio por Cochabamba, que reunía "todas las modificaciones de clima y temperatura del globo entero" (Haenke, 1809:393), era tal que permaneció allí hasta su muerte.

La admiración de Haenke por la Naturaleza del Nuevo Mundo no se extendía a sus habitantes. Sus reflexiones se asemejan más a la de otros viajeros peninsulares españoles que a la taxonomía de historia natural de Rodrigues Ferreira, empleando incluso el sistema español de castas. ${ }^{29}$ Así, escribía sobre los criollos criticando su generosidad como causa de todos los males, afirmando que "El chapetón [español peninsular], decía, viene regularmente a edificar a este país; pero el criollo, su hijo, queda para destruir cuanto su padre edificó" (Haenke, 1901:23). La población del Perú crecía en cantidad y no calidad, propagándose los desertores, los polizontes y los vagos. Sin embargo, consideraba que sus cualidades aventajan a los defectos, en particular con respecto a las limeñas (menos hipócritas que las españolas o las italianas). A pesar de que los criollos tenían facilidad para las ciencias y las artes, el país no había avanzado en estos temas debido al decaimiento general de España, apática en estas materias hasta

\footnotetext{
${ }^{28}$ Aunque excede los límites de este trabajo, resulta interesante la vinculación entre observación y teoría en Rodrigues Ferreira. Su autoridad ante otros viajeros, a los que considera menos competentes, está sostenida en su rol de hombre de ciencia. Esta competencia sustenta la veracidad de su testimonio y de sus observaciones. Sin embargo, ignora sus propias observaciones cuando contradicen las obras de sus maestros y el canon a través del cual interpreta la naturaleza. De esta manera, Rodrigues Ferreira nos permite poner en duda el discurso experimentalista de la ciencia ilustrada.

${ }^{29}$ En Historia Natural (1809) el hombre no se incluye en la clasificación, como sí sucede en Rodrigues Ferreira, y su presencia se reduce a la de agente, que modifica y se aprovecha de los recursos naturales.
} 
las Reformas Borbónicas. ${ }^{30}$

$\mathrm{Su}$ análisis sobre el americano nativo presenta ciertas contradicciones: en ocasiones confirma los más críticos postulados antiamericanistas, mientras que en otros se acerca al topos del buen salvaje, resignificado en el siglo XVIII (Lestringant, 1993). Entre los indios hay una división implícita entre los habitantes de las tierras altas y las tierras bajas. Los altoperuanos constituían un "problema que nadie puede resolver porque nadie lo acierta a definir" (Haenke, 1901:98). ${ }^{31}$ El altoperuano era frugal con su propia comida pero voraz con la ajena, era cobarde pero temible en números, era religioso pero supersticioso, tenía intelecto pero malicia. Su constitución física era endeble y evitaba los trabajos fatigosos: “De modo que en fuerza de este análisis puede considerarse al indio como un ser de naturaleza y alma débil, y si bien por falta de robustez no se aplica a grandes trabajos, no cabiendo en su alma, por la cortedad del vaso, la ambición ni el entusiasmo, no se afana por ser, no se afana por saber, ni tampoco por tener." (Haenke, 1901:99). Haenke reproduce, en este caso, la idea que el hombre americano no tenía deseos, ni pasiones ni ambición.

No obstante, estas características respondían a la forma de gobierno más que a una causa ambiental. Durante el Imperio Inca habían carecido de derechos de propiedad individual mientras que los conquistadores españoles habían abusado del servicio personal y las encomiendas. Por estos motivos, los indios altoperuanos no se esforzaban por tener o saber ya que no contribuiría a su propio adelantamiento. En su perpetua desconfianza, juzgaban que todo progreso beneficiaría a otros, en particular al español. El rigor, al que se habían acostumbrado desde los Incas, formaba ya parte de un temperamento que respondía únicamente a la amenaza y al miedo. En este sentido, el tipo de gobierno influía directamente en el carácter. Este tipo de interpretaciones cobraron fuerza en el siglo XVIII, en las que explicaciones de un mayor relativismo antropológico e histórico fueron reemplazando la idea de una naturaleza humana constante en el tiempo y el espacio. En efecto, en este siglo se dio un cambio trascendental en la comprensión de las sociedades humanas: la diferencia cultural, antiguamente explicada como consecuencia de disposiciones psicológicas individuales, fue considerada una indicación de las posiciones que las distintas sociedades humanas habían alcanzado en una escala temporal histórica (Pagden, 1988). ${ }^{32}$

\footnotetext{
${ }^{30}$ Muchos de los juicios de valor sobre el carácter criollo (el despilfarro, la extravagancia, la ociosidad) son similares al discurso de muchos funcionarios peninsulares ilustrados como Doblas, Azara o Viedma.

31 A diferencia de Rodrigues Ferreira, Haenke no tenía interés por la descripción física sino por la espiritual y moral. Por ejemplo, al analizar las poblaciones infieles menciona que capachos y chipeos al ser blancos constituyen una excepción al color cobrizo del americano, pero no le interesa indagar en las causas.

${ }^{32} \mathrm{Al}$ rastrear los argumentos empleados para legitimar la conquista española, así como el descubrimiento de un grupo humano diferente sobre el que España reclamaba soberanía, Pagden encuentra que en un
} 
La ociosidad americana desesperaba a Haenke, quien la considera el origen de todos los vicios y sobre todo perjudicial para la corona. ${ }^{33}$ Debía ser combatida buscando “...un medio que concilie ambos extremos, haga industrioso al indio en beneficio propio y del Estado, y evite al mismo tiempo la antigua opresión que tanto ha fatigado la pluma de los regnícolas, y de los extranjeros, para opacar la humanidad española..." (Haenke, 1901:115). Por indolencia y costumbre los indios debían ser estimulados al trabajo con cierto rigor y aunque esto pareciera vulnerar la libertad del hombre, para Haenke la libertad no consistía en una completa autonomía sino en hacer lo más adecuado para la sociedad.

Su análisis sobre los indígenas de las tierras bajas, tanto conversos como infieles es diferente. ${ }^{34}$ Para Haenke, estos últimos, inmunes a la actividad misionera, continuaban en sus errores y vida inculta. Eran lascivos, inconstantes en sus relaciones conyugales y practicaban los infanticidios y la antropofagia. Sin embargo, eran generosos, diestros en la pesca y caza, fuertes y habilidosos en sus canoas. En su opinión, el problema de la infidelidad podía resolverse fácilmente estableciendo poblaciones fronterizas. De este modo, los bárbaros

"respirarían, bajo el yugo de suaves leyes, el aire de humanidad que, por su desgracia, no conocen en el día; y abrazarían gustosos el ventajoso estado del orden y la policía que asegura la propiedad de los bienes, y su abundancia, adorando desde aquellas rústicas chozas el paternal amor de nuestros católicos monarcas que tanto se desvelan por su mejor suerte" (Haenke, 1901:231).

Al referirse a los indígenas conversos que habitaban las misiones selváticas Haenke se acercaba al topos del buen salvaje. ${ }^{35}$ El hecho que haya tenido en su juventud

primer momento se empleó la teoría de la esclavitud natural de Aristóteles; esta fue prontamente reemplazada por los esquemas de la psicología aristotélica de la disposición mental de los niños, en la que la tutela del indígena era el deber de un buen cristiano; finalmente se explicaron las diferencias en el comportamiento cultural humano como resultado del condicionamiento social, es decir el concepto de habituación de Aristóteles. Un aspecto interesante del análisis desarrollado por Pagden (1988) es que devela la continuidad de los escritos grecolatinos como modelos autorizados para hacer inteligible al mundo. Es decir, esta resistencia del paradigma aristotélico se evidencia en el reemplazo sucesivo de algunos de sus componentes teóricos como esquemas explicativos.

${ }^{33}$ Debemos aclarar que para Haenke la pereza no era exclusiva de los indígenas altoperuanos. Tanto criollos como mestizos, adormecidos por años de indolencia y de producir solo para el mercado doméstico, no participaban en industrias que podrían ser beneficiosas para el país.

${ }^{34}$ Para esta sección, Haenke indica que se basó en un mapa realizado por Antonio Baleato de 1795, en una relación entregada al Marqués de Osorno, Virrey del Perú y en algunas noticias del Mercurio Peruano. No hemos podido determinar la información que surge de estas fuentes y cual de primera mano.

35 Estas reflexiones fueron tomadas de la Descripción del Perú, Historia Natural y Memoria sobre ríos navegables. 
la intención de ser misionero es un factor relevante ya que su primer contacto con el Nuevo Mundo fue a través de la propaganda misionera, en particular la escrita por jesuitas expulsos, la cual divulgaba una imagen más benevolente de los americanos que los viajeros retomados por Rodrigues Ferreira (Krizová, 2013). Al igual que los infieles, los neófitos eran excelentes marineros, ágiles, diestros e incansables. Según Haenke, eran dóciles, habilidosos e industriosos, en particular en el tejido. La labor de los misioneros, particularmente los jesuitas, había sido fundamental para educar a unos hombres que en la América Meridional se presentaban "...en el estado de su ferocidad, así como salió de la mano de la naturaleza, sin sujeción o otra ley que la superior fuerza, agitado de violentas pasiones, los únicos resortes de sus acciones; en una palabra una bestia furiosa, con la sola forma exterior del hombre" (Haenke, 1901:319). Haenke compartía la idea de que existían etapas de progreso en las sociedades humanas y que a través de la educación se podía facilitar la transición del estado de ferocidad al de la civilización. Los Moxos eran un buen ejemplo de este proceso:

“La nación vecina de Moxos ha hecho, en este género de industria, más progreso que ninguna otra del continente, gracias al método empleados por los españoles conquistadores para instruirles. No se contentaron con sacar a estas personas del estado de barbarie, más fueron al mismo tiempo sus benefactores y sus maestros, en una palabra sus padres, tanto para lo espiritual, como para lo temporal" (Haenke, 1809:538).

Su confianza en el progreso lo llevó a afirmar que de tener acceso a la mejor tecnología europea "se verá que los habitantes de esta parte de la América tienen tanta aptitud y habilidad para las artes, que aquellos del antiguo continente" (Haenke, 1809:538). Sin embargo, el camino hacia la civilización no era unívoco sino que podían existir retrocesos, como había sucedido en algunas Misiones tras la expulsión de los jesuitas.

En su opinión la diferencia de carácter entre indios de tierras altas y bajas no podía ser causada por el continente que compartían. La naturaleza americana, que maravillaba y asombraba al bohemio, no era la causa de la pereza sino que era la clave para la felicidad del hombre. La diferencia se encontraba en el modelo de gobierno, particularmente exitoso en el caso misionero. A pesar de las críticas, este viajero consideraba que la conquista en general había sido positiva para los americanos, en particular la española debido a su compromiso con la evangelización:

“...Se han gastado con generosidad y sin reparo inmensas sumas en esta conquistas espirituales, pero con varios sucesos y progresos más o menos felices en diferentes épocas. En el día, extinguido ya el entusiasmo que en otros tiempos inflamaba a todo el mundo para conquistas, no se deben mirar los misioneros como meros 
conquistadores espirituales sino también como temporales, siendo ellos actualmente los únicos por cuya mano siguen o se pierden las conquistas de las naciones bárbaras, y con ellas los países y provincias que habitan" (Haenke, 1901: 318)

A pesar de la supervivencia de las supersticiones confiaba que el tiempo y el celo constante de los religiosos lograría erradicarlas. El contacto con sociedades criollas también contribuía al aumento del progreso, ya que los indios de Lima eran más "adelantados" que los que vivían en los pueblos. Al analizar los distintos grupos sociales, los temas de la educación, la industria y el progreso están siempre presentes y vinculados exclusivamente a la forma de gobierno. Por ejemplo, opinaba que los limeños no habían podido progresar en las ciencias y las artes, a pesar de sus talentos naturales, debido al decaimiento de la Monarquía Española.

Una comparación de las concepciones sobre el hombre de Tadeo Haenke y Alexandre Rodrigues Ferreira refleja la tensión ilustrada entre los principios de universalidad y el reconocimiento de la diversidad humana. Mientras que el segundo se acercaba a las explicaciones de causación ambiental, el primero vinculaba las diferencias a factores de tipo socio político. En esta distinción podemos observar tanto las trayectorias personales de estos sujetos como su vínculo con tendencias intelectuales al interior de la Ilustración. A lo largo de su vida, Rodrigues Ferreira, por formación e interés, mantuvo un vínculo estable con su campo de investigación. Su elección de residir en Portugal lo mantuvo cercano a los círculos intelectuales europeos y le permitió participar en los debates que se dieron en el área de la historia natural. Este interés se evidencia en Viagem, donde opinó sobre distintas discusiones sobre América, como la causa de las diferencias entre animales, el color de la piel de los hombres o el poblamiento del Nuevo Mundo. En este sentido, viajó con el objetivo de encontrar evidencia empírica y observaciones confiables que demostrasen las teorías desarrolladas por sus mentores intelectuales. Así, su profundización de la variedad Americanus del género Homo fue un aporte al proyecto taxonómico emprendido por la comunidad científica de manera colaborativa. El recuento de deformidades, artificiales y naturales, brindaron datos concretos sobre la categorización linneana. Por ejemplo, insistió en que ciertas variedades del tipo Homo, como el Caudatus, correspondían a deformaciones individuales y no a especies, contradiciendo así a los principales discípulos de Linneo. Su propia formación intelectual y teórica, en particular la influencia de Buffon y Robertson, lo dirigió a responsabilizar de las características morales y espirituales del americano a la naturaleza, que en su exuberancia y abundancia facilitaba los amores, la promiscuidad y la pereza. Aunque como Robertson y Buffon destacó la labor evangelizadora y civilizadora de las potencias europeas, la presencia de este tipo de argumentos en su reflexión es limitada. Todos estos factores contribuyeron a que Rodrigues Ferreira sostuviera la preeminencia de lo natural por 
sobre lo sociocultural como factor determinante de la diversidad social.

En Haenke resulta evidente el problema que implicaba conciliar el concepto de perfectibilidad humana con las apreciaciones negativas sobre los americanos. Sin embargo, los salvajes, bestias furiosas y pasionales habían sido incorporados a la vida civilizada gracias a la educación y evangelización proporcionada por los misioneros. En su opinión, civilización equivalía a razón y el camino hacia una mayor racionalidad dependía del buen gobierno. Monarquista a ultranza, estimaba que había una diferencia considerable entre las directivas metropolitanas y las acciones llevadas a cabo por las autoridades coloniales. Así, los altoperuanos habían sido condenados al gobierno despótico de los Incas primero y a una serie gobernadores locales después. El abuso y excesos de los españoles, jueces inferiores y demás funcionarios fueron los causantes de que "los males que haya padecido y padece el indio son los efectos inevitables de una colonia situada a cuatro mil leguas de su metrópoli" (Haenke, 1901:115).

Haenke fue un fervoroso creyente en la civilización, la razón y la industria. A pesar de tratarse de un hombre de ciencia, en sus informes abundan los elementos utilitaristas y pragmáticos que indican el camino hacia la civilización, entendida como el desarrollo de la industria, el comercio y la ciencia. La vía hacia el progreso del hombre estaba asociada con el cristianismo y el trabajo, de una manera mucho más explícita que en Rodrigues Ferreira, para quien el adelantamiento de los americanos no era una preocupación. Como muchos ilustrados, el bohemio afirmaba que el consumo y el comercio refinaban las facultades del hombre al aumentar la amplitud de sus deseos (Pagden, 1993).

La noción de progreso, como resultado de una mayor racionalidad, implicaba ciertas tendencias evolutivas: se cambiaba en una dirección valiosa y satisfactoria. Sin embargo, el progreso no era inevitable para los iluministas y la idea de leyes naturales ineludibles fue un razonamiento del siglo XIX (Harris, 1996). La humanidad podía retroceder y degradarse, siendo la creencia en el valor del progreso y la civilización más bien un pensamiento optimista que determinista (Harris, 1996). Este aspecto explica el énfasis puesto por la corona, por altos funcionarios de las administraciones coloniales y por viajeros ilustrados en la educación de los habitantes de las colonias americanas, en particular las poblaciones indígenas, para convertirlos en vasallos leales y útiles al Rey. Así como en el siglo XVI las coronas de España y Portugal impulsaron misiones de evangelización para crear buenos cristianos, a finales del siglo XVIII se ideó una agenda civilizadora con el objetivo de crear buenos súbditos.

No obstante, determinar el grado de recepción estos naturalistas obtuvieron en las cortes ibéricas resulta problemático. Siguiendo a Rodriguez García (2015), las valoraciones sobre Rodrigues Ferreira oscilan entre calificarlo como uno de los naturalistas más importantes que recorrieron Brasil y considerar que su expedición 
resultó un fracaso. Para esta autora, estas apreciaciones ponen de manifiesto el carácter cultural, y por lo tanto cambiante en el tiempo, de los conceptos de éxito o fracaso (Rodriguez García, 2015). A su regreso a Portugal, Rodrigues Ferreira no consiguió visibilidad pública como naturalista, las academias de ciencias no publicaron sus trabajos y sus manuscritos no fueron difundidos en los círculos académicos de la época. Esta falta de reconocimiento responde a las características de su obra (sobre la que pesaron fuertemente los objetivos de la Corona portuguesa), a las particularidades de la Ilustración portuguesa y al contexto sociopolítico. Las directivas de la Corona lo llevaron a destacar el carácter económico y utilitario de la naturaleza amazónica en detrimento de aquellas cuestiones científicas que hubieran repercutido en los círculos eruditos europeos (Rodríguez García, 2015). ${ }^{36}$ Por otra parte, las observaciones recogidas por Rodrigues Ferreira correspondían al tipo de información que la Corona deseaba mantener reservada de otros imperios, particularmente en una región de disputa territorial con España (Domingues, 2010). Finalmente, las invasiones napoleónicas y la dispersión de su legado tras el saqueo francés, llevaron a que sus trabajos no fuesen difundidos. Todos estos factores contribuyeron a un reconocimiento tardío de su obra, cuyos manuscritos fueron en su mayoría publicados a mediados del siglo XIX.

Aunque muchos de sus escritos no tuvieron mejor suerte que los de sus compañeros de la malograda Expedición Malaspina, Haenke logró algunas publicaciones en Europa. Su Historia Natural fue traducida al francés y publicada junto con algunas obras de Azara, quien remarcaba que la lejanía le impedía al bohemio difundir los resultados de sus investigaciones. A su vez, su Bohemia natal compró las colecciones enviadas a Cádiz, que serían publicadas en la monumental obra Reliquiae Haenkeniane (Ramos y Alonso, 2018). Sin embargo, donde resulta indudable la repercusión de su trabajo como naturalista fue en el Virreinato del Río de la Plata. Periódicos como el Telégrafo Mercantil y el Correo de Comercio imprimieron parcialmente algunos de sus informes. Es decir que su Historia Natural tuvo dos destinatarios: por un lado los funcionarios reales, y por el otro la comunidad científica rioplatense (Navallo 2010). ${ }^{37}$ Navallo vincula esta repercusión en tierras americanas con la reacción criolla a la Disputa del Nuevo Mundo. Periódicos como el Telégrafo Mercantil y el Mercurio Peruano eran ámbitos de difusión del ideario ilustrado donde se discutían temas de interés general y local. En este contexto, las descripciones de

\footnotetext{
36 Para Raminelli (1998), esta fuerte vinculación con los intereses estatales explica la debilidad de la historia natural de Rodrigues Ferreira, así como el desfasaje entre su formación y los procedimientos ejecutados en Brasil.

${ }^{37}$ Tras la inestabilidad del período revolucionario, Juan Martín de Pueyrredón solicitó a la Junta de Buenos Aires que lo contratase como naturalista, lo cual muestra la relevancia de Haenke en el ámbito intelectual rioplatense (Navallo, 2011). Sobre la actuación de Haenke en este período ver Polišenský (1981).
} 
Haenke sobre territorios distantes impulsaban la imagen de regiones que podían ser racionalmente administradas, contrarrestando la visión negativa europea (Navallo, 2011).

Aunque tanto Rodrigues Ferreira como Haenke padecieron la dispersión de sus manuscritos, la dificultad de publicación de sus obras y el impacto de los vaivenes políticos, resulta interesante contrastar los ámbitos de circulación de sus ideas. El bohemio continuó siendo presentado como miembro de las academias europeas de ciencia y el prestigio de estas instituciones legitimó su autoridad. Sin embargo, su adscripción a la Sociedad Patriótica Literaria y Económica de Buenos Aires y sus publicaciones en periódicos locales, muestra un desplazamiento en los espacios sociales de producción de conocimiento a los que pertenecía y una inclusión en otras redes (Navallo, 2011). Su inclusión en estas redes de circulación del saber científico, no europeas, le permitieron disfrutar de un mayor reconocimiento en vida. ${ }^{38}$

\section{Reflexiones finales}

A mediados del siglo XVIII, el hombre americano cobró relevancia al ubicarse en el centro de la Disputa del Nuevo Mundo. Este debate reflejó la necesidad ilustrada por conciliar la idea de una unidad psíquica del hombre y el reconocimiento de la diversidad humana. En el terreno de la ciencia, manifestó la dicotomía naturaleza/cultura como factores explicativos de la diferencia. Por ejemplo, el contraste de las concepciones de Haenke y Rodrigues Ferreira sobre la pereza nos permite examinar algunas de las explicaciones que surgieron sobre la diversidad humana. En Haenke, que adjudica al gobierno un rol central en el progreso del hombre, es más clara la misión civilizadora europea. Esto se traduce en una serie de proyectos y propuestas para promover y hacer avanzar a la sociedad americana. El hombre se vincula con la naturaleza en tanto agente transformador. Para Rodrigues Ferreira, cuyo interés radica en insertar al hombre en el reino animal, las diferencias sociales son causadas por el vínculo entre los grupos humanos y su ambiente. En este sentido, estos viajeros tienen preocupaciones diferentes. Sin embargo, ambos están interesados en explicar los orígenes de las diferencias en el hombre. La dicotomía naturaleza y cultura, así como la preeminencia de una sobre la otra como factor explicativo, anticipan las discusiones sobre el hombre que se darán en los siguientes siglos en los campos de la sociología, la antropología y la biología.

Entre estos debates se encuentra el de la raza que, como afirma Stocking, es un problema central del siglo XIX (1982). La idea de capacidades hereditarias inmutables

\footnotetext{
${ }^{38}$ La ausencia de redes de comunicación científica en Brasil pueden explicar la falta de repercusión que los escritos de Rodrigues Ferreira tuvieron en este territorio (Rodríguez García, 2017).
} 
no podía sostenerse con una ideología igualitaria iluminista que consideraba que la razón era el motor de la civilización (Harris, 1996). Sin embargo, la percepción de que las diferencias humanas y los logros culturales estaban asociadas a escalas de progreso sostuvieron una justificación de la esclavitud que sobrevivió al programa de la Ilustración (Schwartz, 1994). Asimismo, la tendencia del siglo XVIII de considerar que ciertos grupos humanos eran inferiores y otros superiores se convirtió velozmente en racismo: el cambio de paradigma incluso puede observarse en los mismos pensadores. Por ejemplo, Georges Cuvier, quien en 1790 afirmaba que la estupidez de los negros de debía a una falta de civilización, en 1817 hablaba de diferencias intrínsecas (Stocking, 1982). La civilización, concebida por los ilustrados como el destino de la humanidad, fue en el siglo XIX prerrogativa de ciertas razas escogidas.

\section{Bibliografía}

Albuquerque de Miranda, Luiz Francisco (2018). “A História das duas Índias e os colonizadores da América", Cadernos de História, Vol. 19, núm. 30, pp. 53-76.

Balta, José. Balta, “Prólogo”. Descripción del Perú, 1901.

Bernand, Carmen (2009). “La marginación de Hispanoamérica por la Historia universal europea (siglos XVIII-XIX)”, Co-herencia, Vol 6. núm. 11, pp. 107-122.

Cañizares Esguerra, Jorge (2007). Cómo escribir la historia del Nuevo Mundo. Historiografías, epistemologías e identidades en el mundo del Atlántico del siglo XVIII, México D.F.: Fondo de Cultura Económica.

Capel, Horacio (1995). "Filosofía y ciencia en los debates sobre el territorio en la España del siglo XVIII" Cuadernos de Estudios del Siglo XVIII, núm. 5, pp. 59-100.

Cicerchia, Ricardo (2000). “De diarios, mapas e inventarios. La narrativa de viaje y la construcción de la modernidad", $19^{\text {th }}$ International Congress of Historical Sciences, University of Oslo, pp. 1-21.

Coelho, Mauro Cezar (2000). “A civilização da Amazônia - Alexandre Rodrigues Ferreira e o Diretório dos Índios: a educação de indígenas e luso-brasileiros pela ótica do trabalho", Revista de História Regional, Vol. 5, núm. 2, pp. 149-174.

Cro, Stelio (1989). “El buen salvaje y la edad moderna. Hackluyt, Montaigne y Pedro Mártir", Actas X, Asociación Internacional de Hispanistas, Barcelona, pp. 397-405.

De Vos, Paula (2009). "The Rare, the Singular, and the Extraordinary: Natural History and the Collection of Curiosities in the Spanish Empire", en: Bleichmar, D., De Vos, P., Huffine, K. y Sheehan, K. (eds.), Science in the Spanish and Portuguese Empires, 1500-1800, Stanford, Stanford University Press. 
Domingues, Ângela (2001). "Para um melhor conhecimento dos domínios coloniais: a constituição de redes de informação no Império português em finais do Setecentos", História, Ciências, Saúde, Vol. VIII, pp. 823-838.

Domingues, Beatriz Helena (2010). “O papel dos jesuítas na Ilustração brasileira “, História Unisinos, Vol 14, núm. 2, pp. 135-147.

Fernández Herrero, Beatriz (1989). “El mito del Buen Salvaje y su representación en el Gobierno de Indias", Agora, Vol 8, pp. 145-150.

Gerbi, Antonio (1982). La disputa del Nuevo Mundo, MéxicoD.F.: Fondo de Cultura Económica.

Greenblatt, Stephen (2008). Maravillosas posesiones: el asombro ante el Nuevo Mundo, Barcelona: Marbot.

González Montero de Espinosa, Marisa (1992). La Ilustración y el hombre americano. Descripciones etnológicas de la Expedición Malaspina, Madrid: Consejo Superior de Investigaciones Científicas.

Guasti, Niccolo (2014). "Los jesuitas españoles expulsos ante la disputa del Nuevo Mundo", en: De Francesco, A., Mascilli Migliorini, L. y Nocera, R. (coord), Entre Mediterráneo y Atlántico. Circulaciones, conexiones y miradas, 1756-1867, Santiago: Fondo de Cultura Económica.

Haenke, Tadeo (1809). "Introduction a l'Histoire naturelle de la province de Cochabamba et des environs, et description de ses productions", En: Azara, F. Voyages dans l'Amerique Méridionale. Vol. 2, Paris: Dentu Imprimeur-Libraire.

Haenke, Tadeo (1901). Descripción del Perú, Lima: Imprenta El Lucero.

Hartog, François, (2005). Anciens, modernes, sauvages, París: Galaade Éditions.

Harris, Marvin (1996). El Desarrollo de la Teoría Antropológica. Historia de las Teorías de la Cultura, Madrid: Siglo XXI.

Israel, Jonathan (2001). Radical Enlightenment. Philosopy and the Making of Modernity 16501750, Oxford: Oxford University Press.

Krizová, Markéta (2013). “Misiones Jesuitas y la imágen de América en Europa. Siglos XVII y XVIII", en: Lillian von der Walde Moheno y Mariel Reinoso Inglioso (eds) Virreinatos II, México D.F. Editorial Grupo Destiempos. México DF.

Kupperman, Karen Ordahl (1995). "The changing definition of America", en: Kupperman, K. O. (ed.) America in European Consciousness, Chapel Hill: University of North Carolina Press, .

Lestringant, Frank (1993). “The Philosopher's Breviary: Jean Léry in the 
Enlightenment", en Greenblatt, S. (ed.) New World Encounters, Berkeley: University of California Press.

Lucena Giraldo, Manuel y Pimentel, Juan (2006). Diez Estudios sobre Literatura de Viajes. Madrid: Consejo Superior de Investigaciones Científicas.

Malik, Kenan (1992). Strange Fruit: why both sides are wrong in the race debate, Londres: Oneworld Publications.

Martínez, Carolina (2016). “Usos del pasado y confiabilidad de las fuentes: AntoineJoseph Pernety y la disputa sobre la naturaleza de América en el siglo XVIII", CORPUS, Vol 5, núm. 2, pp. 1-28.

Melo Carvalho, José Cándido (1972). “Introducción”, En: Rodrigues Ferreira, A. Viagem Filosófica. Pelas las Capitanias do Grao-Para, Rio Negro, Mato Grosso e Cuiabá. Río de Janeiro: Conselho Federal de Cultura.

Moutinho Pataca, Ermelinda y Pinheiro, Rachel (2005). “Instruções de viagem para a investigação científica do território brasileiro", Revista da SBHV, Vol. 3, núm. 1, pp. 5879 .

Navallo, Tatiana (2010). “Ideas ilustradas en el Río de la Plata: de los manuscritos al 'Proiecto Geográfico' del Telégrafo Mercantil (1801-1802)”, Tinkuy, núm. 14, pp. 159197.

Navallo, Tatiana (2011). “La Introducción a la Historia Natural de Tadeo Haenke y las representaciones de la naturaleza en la conformación del Alto Perú", Antítesis, $\mathrm{Vol}^{\circ} 4$, núm. 8, pp. 703-728.

Nieto Olarte, Mauricio (2003). “Historia Natural y la Apropiación del Nuevo Mundo en la Ilustración Española”, Bulletin de l'Institut francais d'études andines, Vol. 32 núm. 3, pp. 417-429.

Outram, Dorinda (2008). Panorama de la Ilustración, Barcelona: Blume.

Pagden, Anthony (1988). La caída delhombre natural, Madrid: Alianza Editorial.

Pagden, Anthony (1993). European encounters with the New World: from Renaissance to Romanticism, New Haven: Yale University Press.

Penhos, Marta (2005). Ver, conocer, dominar. Imágenes de Sudamérica a fines del siglo XVIII, Buenos Aires: Siglo XXI Editores.

Pimentel, Juan (2003). Testigos del Mundo. Ciencia, literatura y viajes en la Ilustración, Madrid: Marcial Pons Ediciones.

Polišenský, Josef (1981). “Tadeo Haenke y la guerra de la Independencia”, Estudios Latinoamericanos, Vol. 8, pp. 103-115. 
Pratt, Mary Louise (1997). Ojos imperiales. Literatura de viajes y transculturación, Quilmes: Universidad Nacional de Quilmes.

Raminelli, Ronald (1998). “Ciência e colonização - Viagem Filosófica de Alexandre Rodrigues Ferreira", Revista Tempo, núm. 6, pp.157-182 .

Ramos, Víctor y Alonso, Ricardo (2018). “Tadeo Haenke: primer naturalista del Virreinato del Río de la Plata", Anales de la Academia Nacional de Ciencias Exactas, Físicas y Naturales, tomo 70, pp. 117-146.

Rodrigues Ferreira, Alexandre (1972). Viagem Filosófica. Pelas las Capitanias do Grao-Para, Rio Negro, Mato Grosso e Cuiabá, Río de Janeiro: Conselho Federal de Cultura.

Rodríguez García, Margarita Eva (2015). “Lejos del gabinete: viajes científicos a la América portuguesa y española (1777-1792) y representación de la naturaleza", Memorias. Revista Digital de Historia y Arqueología desde el Caribe, núm. 25, pp. 144-177.

Rodríguez García, Margarita Eva (2017). “La circulación de conocimientos botánicos sobre el Brasil a finales del Antiguo Régimen", en: O'Phelan Godoy, S. y Rodriguez García, M.E. (coord.), El ocaso del antiguo régimen en los imperios ibéricos, Lima: Pontificia Universidad Católica del Perú.

Schwartz, Stuart (1994). "Introducción", En Schwartz, S. (Ed.): Implicit Understandings. Observing, Reporting, and Reflecting Encounters between Europeans and Other Peoples in the Early Modern Era. Cambridge: Cambridge University Press.

Sebastiani, Silvia. (2011). "Las escrituras de la historia del Nuevo Mundo: Clavijero y Robertson en el contexto de la Ilustración europea." Historia y Grafía, Universidad Iberoamericana, año 19, núm. 37, pp. 203-236

Soriano Muñoz, Nuria (2020). “Las fisuras de la nación: tensiones y lecturas políticoreligiosas sobre la conquista de América en el siglo XVIII", Rubrica Contemporanea, Vol. IX, núm. 17, pp 11-29.

Stocking, George W. Jr. (1982). Race, Culture and Evolution: Essays in the History of Anthropology, Chicago: University of Chicago Press. Chicago.

Ventura, Roberto (1988). “Leituras de Raynal e a ilustração na América Latina”, Estudos Avançados, Vol. 2, núm. 3, pp. 40-51.

Urteaga, Luis (1993). “La teoría de los climas y los orígenes del ambientalismo". Cuadernos Críticos de Geografía Humana, núm. 99, pp. 1-55.

Zeitlin, Irving (1968). Ideology and the development of sociological theory, New Jersey: Prentice-Hall. 